\title{
Assessment of Phytochemical, Antioxidant and Antimicrobial Activities of Some Medicinal Plants from Kaski District of Nepal
}

\author{
Lekha Nath Khanal'1, Khaga Raj Sharma', Yuba Raj Pokharel2 ${ }^{*}$, Surya Kant Kalauni ${ }^{*}$ \\ ${ }^{1}$ Central Department of Chemistry, Tribhuvan University, Kirtipur, Kathmandu, Nepal \\ ${ }^{2}$ Faculty of Life Science and Biotechnology, South Asian University, New Delhi, India \\ Email: *yrp@sau.ac.in, *skkalauni@gmail.com
}

How to cite this paper: Khanal, L.N., Sharma, K.R., Pokharel, Y.R. and Kalauni, S.K. (2020) Assessment of Phytochemical, Antioxidant and Antimicrobial Activities of Some Medicinal Plants from Kaski District of Nepal. American Journal of Plant Sciences, 11, 1383-1397.

https://doi.org/10.4236/ajps.2020.119099

Received: July 29, 2020

Accepted: September 15, 2020

Published: September 18, 2020

Copyright $\odot 2020$ by author(s) and Scientific Research Publishing Inc. This work is licensed under the Creative Commons Attribution International License (CC BY 4.0).

http://creativecommons.org/licenses/by/4.0/

\begin{abstract}
Medicinal plants have been known to treat simple to life-threatening diseases in different communities of Nepal for many years. This study aims to analyze the phytochemicals as plant secondary metabolites, evaluate the antioxidant and antibacterial activities of Rubus ellipticus, Ziziphus mauritiana, Pyrus pashia, and Drynaria coronans extracts that are commonly being used as traditional medicine. Phytochemical analysis was performed to investigate the plant's secondary metabolites such as polyphenols, alkaloids, flavonoids, terpenoids, reducing sugar, glycosides, tannins, carotene, phytosterols, coumarins, saponins, and anthracenes. The methanol extracts of the plants were used to evaluate the in vitro antioxidant activity by using 2,2-Diphenyl-1-picrylhydrazyl (DPPH) radical and the antibacterial activity against Staphylococcus aureus (ATCC 25923), Klebsiella pneumoniae (ATCC 700603), Escherichia coli (ATCC 25922) and Salmonella typhi (ATCC 14028) by the agar well diffusion method. Minimum Inhibitory Concentration (MIC) and Minimum Bactericidal Concentration (MBC) were determined by the Resazurin Microtiter Assay (REMA) method. Root extract of $R$. ellipticus was observed to have the highest antioxidant activity with $\mathrm{IC}_{50}$ of $42.40 \pm 1.5$ $\mu \mathrm{g} / \mathrm{ml}$ followed by the root extract of $Z$. mauritiana $\left(\mathrm{IC}_{50} 55.67 \pm 7.41 \mu \mathrm{g} / \mathrm{ml}\right.$ ), leaf and bark extract of $P$. pashia $\left(\mathrm{IC}_{50} 58.33 \pm 2.9 \mu \mathrm{g} / \mathrm{ml}\right.$ ) and tuber extract of D. coronans $\left(\mathrm{IC}_{50} 93.30 \pm 5.19 \mu \mathrm{g} / \mathrm{ml}\right.$ ) as compared to the standard ascorbic acid with $\mathrm{IC}_{50}$ of $28.44 \pm 0.97 \mu \mathrm{g} / \mathrm{ml}$. The plants were found active against Gram-positive Staphylococcus aureus with Zone of Inhibition (ZOI) for $R$. ellipicus $17 \mathrm{~mm}, P$. pashia $12 \mathrm{~mm}, Z$. mauritiana $9 \mathrm{~mm}$ and $D$. coronans $8 \mathrm{~mm}$. The extracts exhibited no effect on all of the tested Gram-negative bacteria. The MIC and MBC of $R$. ellipticus and $P$. pashia were $3.125 \mathrm{mg} / \mathrm{ml}, 12.5$ $\mathrm{mg} / \mathrm{ml}$, and $12.5 \mathrm{mg} / \mathrm{ml}, 25 \mathrm{mg} / \mathrm{ml}$ respectively.
\end{abstract}




\section{Keywords}

Medicinal Plant, Phytochemical, Antioxidant, Antibacterial Activity, Resazurin

\section{Introduction}

Different plants and plant-derived products are being used as medicine since the dawn of human civilization. Around $75 \%-80 \%$ of the world's population residing in the developing countries rely on herbal remedies for primary healthcare because of their cultural acceptability and fewer side effects [1]. The application of plants as medicine had been enlightened in the holy book of Hindus "RIGVEDA". This book is considered as the earliest repository which was written nearly in 4500 BC [2]. Traditional Chinese Medicine (TCM), Tibetan Amchi Medicine (TAC), and other alternative medicinal systems are common in Nepal. These practices have been utilized and transferred from generations for hundreds to thousands of years and are still in practice today [3].

The extreme variation in topography, climate, and soil in a small geographic area has led Nepal to have diverse biodiversity with more than 7000 species of medicinal plants [4]. The secondary metabolites such as glycosides, tannins, phenolics, lipids, alkaloids, terpenoids, etc. are responsible for the pharmacological activities of the plants which have significant importance to mankind [5]. Diverse biochemical reactions in our body generate an unbalanced quantity of free radicals creating abnormal physiological conditions leading to oxidative damage of lipids, proteins, and other important biomolecules. This damage plays a key role in the overexpression of oncogenes, mutagens formation, induction of atherogenic activity, etc. Oxidative stress is responsible for the development of many chronic illnesses such as cancers, diabetics, cardiovascular disorder, neurodegeneration, aging, and others. Natural antioxidants repair the damage caused by the reactive oxygen species (ROS). They constantly convert the free radical into less harmful molecules by radical chain reactions [6].

With the progress of science and technology, scientists have established different kinds of antibiotics to control several pathogens in the $20^{\text {th }}$ century. The emergence of multidrug resistance bacteria, pan-drug resistance bacteria, as well as misuse of antibiotics, had posed a serious challenge to the synthetic compounds. Researchers are now dedicated to the progress of benign biologically active plant-derived compounds to use for the development of novel drugs [3]. The drugs from plant sources are relatively non-toxic, safe, and free from serious side effects [7]. Therefore, there is an urgent need to search of active natural compounds from medicinal plants which can potentially be effective in the treatment of the awkward bacterial infections.

The local people of Kaski district of Nepal use different medicinal plants for their primary healthcare purposes. For this study, the most common plants 
namely $R$. ellipticus, $P$. pashia, D. coronans and $Z$. mauritiana were taken (Figure 1). R. ellipticus SM. belongs to family Rosaceae and is commonly known as Himalayan Raspberry (Figure 1a). It comprises of more than 750 species in 12 subgenera and found in forest edges and mountains on all continents except Antarctica. The root juice is used for fever, gastric, diarrhea, dysentery, and the root-paste is applied to wounds [8]. In western Nepal, the root juice is drunk against urinary tract infection and the fruits are listed in the top-ten edible medicinal plants in Tanahun District [9]. P. pashia Buch, Ham. ex D. Don (Figure 1b) belonging to family Rosaceae is abundant in Nepal, China, India, Bhutan, Pakistan, Myanmar, Thailand, Vietnam, Laos, and Afghanistan [10]. The fruits are used in the treatment of dyspepsia and dysmenorrhea. Flowers are used to lowering blood lipids and branches for diarrhea in Chinese folk medicine [11]. Local people of Kaski district use the decoction of leaves and stem bark for the treatment of fever and headache. Z. mauritiana Lam (Figure 1c) is a medium-sized plant of the Rhamnaceae family. It is distributed in Bangladesh, India, Sri Lanka, and other South-East Asian countries [12]. The leaves had been used in the treatment of liver disease, asthma, and fever. Fruits are used in hyperdipsia, vomiting, nausea, dyspepsia, wounds, and ulcers [13]. In the Parbat district of central Nepal, a decoction of root bark is taken for the menstrual disorder, fever, dysentery, and diarrhea [14]. D. coronans (Figure 1d) is an epiphytic fern belonging to family polypodiaceae. It is abundant in different parts of Nepal and has been used against different health problems. Its roots are used for diarrhea and constipation [15].

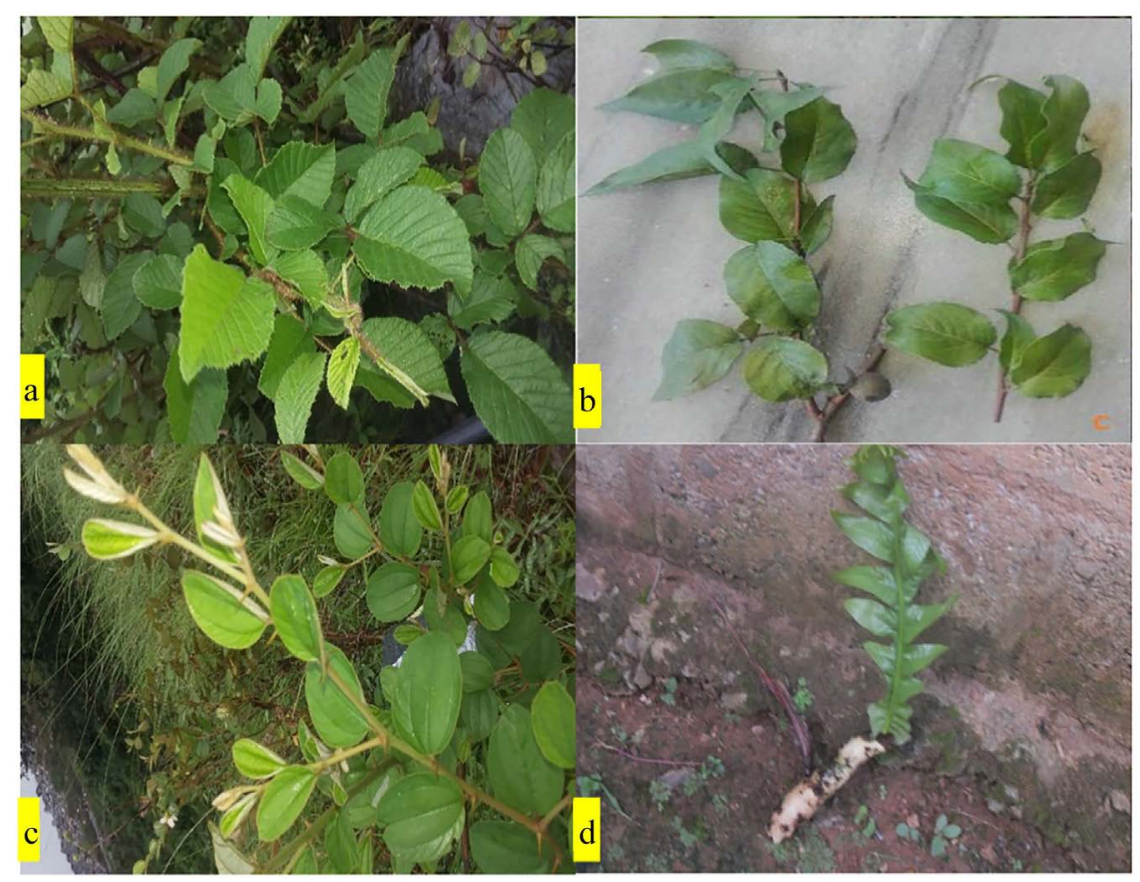

Figure 1. Collected medicinal plants of Kaski district of Nepal: a. R. ellipticus, b. $P$. pashia, c. Z. mauritiana, d. D. coronans. 
The plants were found to be extensively used by the locals and were readily available in the region. The study is aimed to assess the in-vitro antioxidant and antibacterial activities of some of the most commonly used plants as traditional medicine. This research provides a scientific background of the traditional use of plants by the local people.

\section{Materials and Methods}

\subsection{Collection of Plant Materials}

The plant materials were collected from the outskirts of Pokhara and Rupa village of Kaski district. The samples were collected from July 2018 to April 2019. The plants were authenticated at the National Herbarium and Plant Laboratories, Lalitpur, and the voucher specimen has been submitted to the same department. The list of plants with local names, parts used, collected site, and traditional uses are shown in Table 1.

\subsection{Preparation of Extract}

The collected samples were washed with clean water and dried in the shed for about three weeks. The dry samples were chopped into pieces and ground into powder by using a mechanical grinder. The powdered materials were stored in clean plastic bottles until the use. The materials were subjected to Soxhlet's extraction using $80 \%$ methanol as a solvent. The extracts were concentrated in a rotary evaporator. The extracts were stored at $4^{\circ} \mathrm{C}$ before performing the biological activities.

\subsection{Phytochemical Screening}

The methanol extracts of all the plant extracts were tested for the presence of different phytochemicals. The tests were performed for the presence of polyphenols, alkaloids, flavonoids, terpenoids, reducing sugar, glycosides, tannins, carotene, phytosterols, coumarins, saponins, and anthracenes by adopting standard protocols [17] [18].

Table 1. List of plants with local names, parts used, collected site and traditional uses.

\begin{tabular}{|c|c|c|c|c|}
\hline $\begin{array}{l}\text { Plant } \\
\text { samples }\end{array}$ & $\begin{array}{l}\text { Local } \\
\text { name }\end{array}$ & $\begin{array}{l}\text { Parts } \\
\text { used }\end{array}$ & $\begin{array}{l}\text { Collected } \\
\text { from }\end{array}$ & $\begin{array}{l}\text { Traditional } \\
\text { use }\end{array}$ \\
\hline Ziziphus mauritiana Lam. & Bayer & Root bark & Pokhara, Kaski & $\begin{array}{l}\text { Menstrual disorder, } \\
\text { fever }[14]\end{array}$ \\
\hline Rubus ellipticus $\mathrm{Sm}$. & Yensalu & Root bark & Pokhara, Kaski & $\begin{array}{l}\text { Dysentery, gastric and } \\
\text { fever }[8]\end{array}$ \\
\hline $\begin{array}{l}\text { Pyrus pashia Buch. Ham. } \\
\text { Ex D. Don. }\end{array}$ & Mel & $\begin{array}{l}\text { Fruit, bark, } \\
\text { leaves }\end{array}$ & Rupa, Kaski & $\begin{array}{l}\text { dyspepsia and } \\
\text { dysmenorrhea [11] }\end{array}$ \\
\hline $\begin{array}{l}\text { Drynaria Coronans } \\
\text { (Wall. Ex. Mett.) T. Moore }\end{array}$ & Kammaru & Tuber & Rupa, Kaski & Bone injury [16] \\
\hline
\end{tabular}




\subsection{Antibacterial Activity}

\subsubsection{Microorganisms}

Pure cultures of all the tested bacteria were obtained from the American Type Culture Collection (ATCC) of the Central Department of Microbiology, Tribhuvan University, Kirtipur. The pure cultures were maintained on the Muller Hinton Agar (MHA) media at $4^{\circ} \mathrm{C}$ and sub-cultured. The list of organisms used is shown in Table 2.

\subsubsection{Agar Well Diffusion Assay}

The bacterial susceptibility of the plants' extract was assessed by the agar well diffusion method in Mueller Hinton Agar plates [19]. The agar-well diffusion method is a very simple and reliable method of determination of antibacterial susceptibility. The test bacteria are grown on the surface of an agar medium. The test samples are loaded into the sterile wells on the agar surface bored aseptically. The antibacterial agent of a certain quantity is allowed to diffuse through the medium at $35^{\circ} \mathrm{C}-37^{\circ} \mathrm{C}$ for $24-48$ hours depending upon the test organism. The inhibition of bacterial growth corresponds to the diameter of the no-growth region on the medium [20].

The test organisms were incubated in Mueller Hinton Agar Broth (MHB) overnight at $37^{\circ} \mathrm{C}$ to adjust the turbidity equivalent to $0.5 \mathrm{McFarland}$ 's standards $\left(1.5 \times 10^{8} \mathrm{CFU} / \mathrm{ml}\right)$. The plates were carpet-cultured on the surface of agar by a sterile cotton swab and five wells of $6 \mathrm{~mm}$ diameter were bored at equal distances with the help of a sterile cork-borer. Plant extract of $50 \mathrm{mg} / \mathrm{ml}$ concentration were prepared in 50\% dimethyl sulphoxide (DMSO). Neomycin $(1 \mathrm{mg} / \mathrm{ml})$ in autoclaved distilled water was taken as a positive control and 50\% DMSO as a negative control. Each well was filled with $20 \mu \mathrm{l}$ extracts, positive, and negative controls were incubated for 24 hours at $37^{\circ} \mathrm{C}$. After incubation, the plates were observed for the formation of a clear zone around the well which corresponds to the antibacterial activity of the sample. The zone of inhibition (ZOI) of each sample was measured in $\mathrm{mm}$ and recorded.

\subsubsection{Resazurin Microtiter Assay (REMA)}

The extracts of Rubus ellipticus and Pyrus pashia exhibiting maximum ZOI against Staphylococcus aureus were selected for the determination of MIC and MBC by resazurin microtiter assay. This method is a simple, rapid, sensitive, and reliable method to assess the antibacterial properties of natural products. It uses

Table 2. List of bacterial cultures.

\begin{tabular}{ccc}
\hline Bacteria & Type & ATCC \\
\hline Staphylococcus aureus & Gram-positive & 25923 \\
Klebsiella pneumoniae & Gram-negative & 700603 \\
Escherichia coli & Gram-negative & 25922 \\
Salmonella typhi & Gram-negative & 14028 \\
\hline
\end{tabular}


an indicator, resazurin that allows the detection of microbial growth in extremely small volume in the microtiter plate without using a spectrophotometer. In a 96-well microtiter plate, test materials are loaded in a sequence of serial dilution and the development of bacteria in a particular solution can be noticed by the change of color of the indicator. The use of resazurin is to detect visually the living and dead cells in the system. The dye is converted into pink color due to the $\mathrm{NADH}$ enzymes produced by the living cells [21].

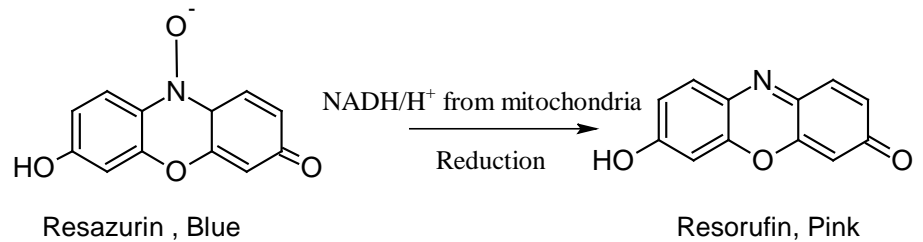

Plant extracts were dissolved in 50\% DMSO into a concentration of 100 $\mathrm{mg} / \mathrm{ml}$. The bacteria were cultured into the Muller Hinton Broth (MHB) overnight at $37^{\circ} \mathrm{C}$ by using a sterile loop. The next day, the colony was sub-cultured into the broth at $37^{\circ} \mathrm{C}$ for about two hours to match with $0.5 \mathrm{McF}$ arland's standard $\left(1.5 \times 10^{8} \mathrm{CFU} / \mathrm{ml}\right)$ solution. The culture was diluted $1 / 100$ times into the broth so that bacterial concentration converted into $1.5 \times 10^{6} \mathrm{CFU} / \mathrm{ml} .50 \mu \mathrm{l}$ of the broth is loaded into all well from 1 to 6 (for two sets of triplicates) plant extracts) and 7, 8, and 9 are set up for neomycin $(1 \mathrm{mg} / \mathrm{ml}$ in distilled water and syringe filtered) as a positive control. Similarly, 10,11 , and $12^{\text {th }}$ are filled with $100 \mu \mathrm{l}$ of the broth to set up the negative control. Each of the well from 1 to 9 is filled by $100 \mu \mathrm{l}$ of the broth using a multichannel pipette. The solutions from the topmost row are serially subjected to twofold diluted using a multichannel pipette up to the eighth row. Then each of the wells is loaded by $5 \mu$ of the bacterial culture solution and allowed to incubate at $37^{\circ} \mathrm{C}$ with lid covered for about 18 to 24 hours. The plate was taken out and $30 \mu \mathrm{l}$ of $0.01 \%$ resazurin was added into each of the wells and again incubated for about 2 hours in the incubator at $37^{\circ} \mathrm{C}$. Finally, the microtiter plate is taken out and the visual change of color of the solutions observes and the MIC is determined as the concentration that corresponds to the no development of bacteria as shown in Figure 2. The solutions in the wells with a pink color corresponding to the MIC and stronger solutions were streaked onto the MHA plates at different compartments and incubated overnight at $37^{\circ} \mathrm{C}$.

The next day, the solutions of the compartments corresponding to MIC to higher concentrations were seeded on Muller-Hinton Agar media. The minimum concentration corresponding to no growth of bacteria was noted as the $\mathrm{MBC}$ of the corresponding plant extract.

\subsection{Antioxidant Activity}

The antioxidant activity of the plant extracts was determined by 2-2-Diphenyl-1picrylhydrazyl free radical scavenging assay using a 96-well plate reader with slight modifications [22] [23]. 


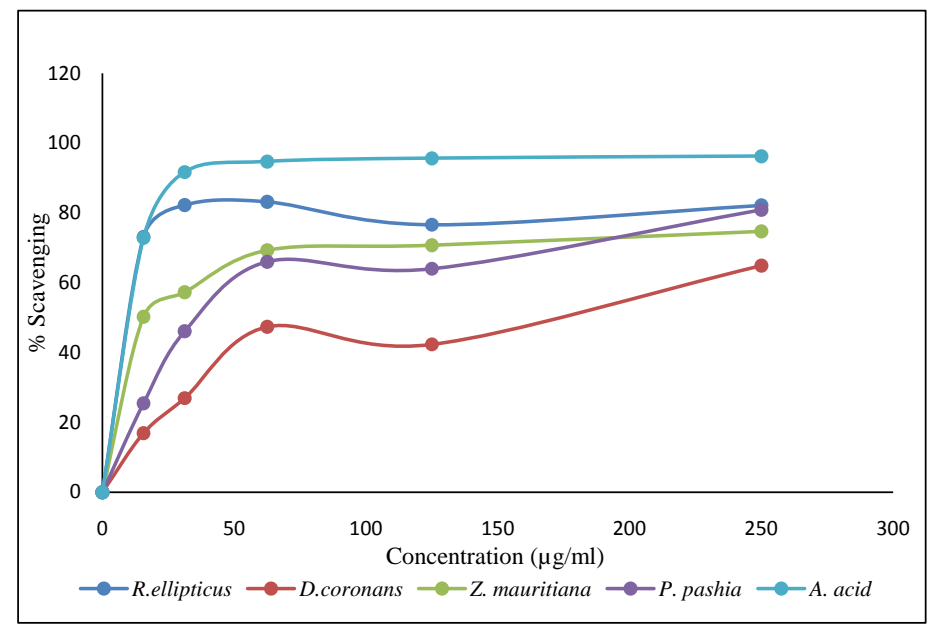

Figure 2. DPPH scavenging activities of different plant extracts against the concentration.

2,2-Diphenyl-1-picrylhydrazyl (DPPH) has a molecular weight of 394.32 $\mathrm{g} / \mathrm{mol}$. Thus, $0.1 \mathrm{mM}$ solution of the compound was prepared by dissolving $1 \mathrm{mg}$ in methanol to adjust $25 \mathrm{ml}$ in a volumetric flask. The solution was stored by covering with black paper and aluminum foil in a frost-free refrigerator at $4{ }^{\circ} \mathrm{C}$.

First of all, $10 \mathrm{mg}$ of the extract is dissolved in $10 \mathrm{ml}$ of dimethyl sulphoxide (DMSO) to get the stock solution $(1000 \mu \mathrm{g} / \mathrm{ml})$ and two-fold diluted using $50 \%$ DMSO. The microplate wells are vertically labeled serially for the solutions as $500,250,125,62.5,31.25,15.62 \mu \mathrm{g} / \mathrm{ml}$ in triplicate. $100 \mu \mathrm{l}$ of the solutions of each concentration and $100 \mu \mathrm{l}$ of DPPH is filled. The same setting was adjusted for the standard ascorbic acid as well as a negative control. The microplate was allowed to incubate at room temperature for about 30 minutes in dark. Then, the plate was loaded into the microplate reader (BioTek, Synergy LX multimode reader) at $517 \mathrm{~nm}$ and the data was recorded. The percentage scavenging was calculated by using the formula:

$$
\% \text { Scavenging }=\frac{\text { Absorbance of Control }- \text { Absorbance of sample }}{\text { Absorbance of control }} \times 100
$$

The percentage scavenging of the samples at different concentrations are used to calculate the concentration inhibiting $50 \%$ of the radical by using linear regression analysis.

\subsection{Data Processing}

Data obtained from the experiments were processed carefully. Mean, standard deviation, and standard error of means was calculated by using Microsoft Excel 2016. Concentration causing 50\% inhibition $\left(\mathrm{IC}_{50}\right)$ was calculated by using probit analysis table.

\section{Results and Discussions}

The result of the phytochemical study is shown in Table 3. The phytochemical 
investigation showed the presence of polyphenols, glycosides, reducing sugar, flavonoids, and tannins. Saponins were present in P. pashia which did not show the presence of carotenoids. Carotenoids were detected in R. ellipticus only. A trace presence of anthracene was detected on $P$. pashia and $D$. coronans. Alkaloids saponins and phytosterols were detected in trace amounts. Alkaloids are the special group of nitrogenous compounds used during middle ages against various human and animal ailments. Tannins are a group of high molecular weight polyphenols that protect plants from microorganisms. In animals, they cause indigestion of protein leading to a retardation of growth [24]. Flavonoids and polyphenols are important human dietary compounds that could be used for the prevention of radiation damage, treatment of cancer, cardiovascular and inflammatory diseases [25].

\subsection{Antioxidant Activity}

The DPPH antioxidant assay provides information on the reactivity of the plant extracts with the stable free-radical. It is a relatively stable nitrogen-containing radical having pink color. It is easily reduced by accepting an electron or a hydrogen atom from the antioxidants and loses pink color. The loss of color depends on the number of electrons accepted and it can be quantitatively measured by the changes of absorption of light of $517 \mathrm{~nm}$ [26]. The graph of the concentration against the corresponding percentage scavenging of different extrats and ascorbic acid is shown in Figure 1. The percentage scavenging of $R$. ellipticus, $P$. pashia, and $Z$. Mauritiana show an analogous mode of variation with that of ascorbic acid standard but that of $D$. coronans moves somewhat below from them.

Table 3. Result of preliminary qualitative phytochemical analysis.

\begin{tabular}{ccccc}
\hline Phytochemicals & Ziziphus mauritiana & Pyrus pashia & Rubus ellipticus & Drynaria coronans \\
\hline Polyphenols & ++ & ++ & ++ & ++ \\
Alkaloids & ++ & + & + & + \\
Glycosides & ++ & + & ++ & + \\
Reducing sugar & ++ & ++ & ++ & + \\
Flavonoids & ++ & + & ++ & + \\
Terpenoids & + & + & ++ & + \\
Tannins & ++ & + & + & + \\
Coumarins & - & ++ & + & + \\
Saponins & + & ++ & + & + \\
Carotenoids & - & - & + & - \\
Phytosterol & + & + & - & + \\
Anthracene & - & + & - & + \\
\hline
\end{tabular}

$+=$ Present, $-=$ Absent. 
The concentrations causing $50 \%$ inhibition of the free radical $\left(\mathrm{IC}_{50}\right)$ values were calculated graphically.

The result presented in Table 4 reveals that the extracts of $R$. ellipticus had the maximum antioxidant activity with the lowest $\mathrm{IC}_{50}$ value $(42.40 \pm 1.5 \mu \mathrm{g} / \mathrm{ml})$ followed by $Z$. mauritiana $(55.67 \pm 7.4 \mu \mathrm{g} / \mathrm{ml})$ and $P$. pashia $(58.33 \pm 2.9 \mu \mathrm{g} / \mathrm{ml})$. The extract of $D$. coronans exhibited the minimum antioxidant activity with maximum $\mathrm{IC}_{50}$ of $93.30 \pm 5.19 \mu \mathrm{g} / \mathrm{ml}$. The higher antioxidant activity of the root extracts of $R$. ellipticus is in agreement with the $\mathrm{IC}_{50}$ value of $33.41 \mu \mathrm{g} / \mathrm{ml}$ exhibited by the methanolic extracts of the leaves of $R$. ellipticus from the Arghakhanchi district of Nepal [27]. The antioxidant activity of the leaf extracts of $R$. ellipticus in different solvents was evaluated by DPPH scavenging assay. The methanol extract was found to exhibit the maximum antioxidant property with $\mathrm{IC}_{50}$ of $6.96 \pm 2.32 \mu \mathrm{g} / \mathrm{ml}$ while that of standard butylated hydroxytoluene (BHT) was $13.18 \pm 1.43 \mu \mathrm{g} / \mathrm{ml}$. The extract at the dose of $250 \mathrm{mg} / \mathrm{Kg}$ was found to prolong the life span of Swiss albino mice with Ehrlich ascites carcinoma by $46.76 \%$ and reduced the volume of solid tumor of Dalton's lymphoma ascites by $2.56 \mathrm{~cm}^{3}$ [28]. The higher antioxidant activity of $R$. ellipticus may be due to the abundance of important phytochemicals like polyphenols, flavonoids, glycosides which are known for the antioxidant activity [29]. The antioxidant activities of leaf extracts of $P$. pashia of Indian origin were evaluated by DPPH scavenging assay taking ascorbic acid as a standard. The methanol and water extracts were found to exhibit a significant activity with $\mathrm{IC}_{50}$ values of $10.81 \pm 0.44 \mu \mathrm{g} / \mathrm{ml}$ and $11.57 \pm 0.36 \mu \mathrm{g} / \mathrm{ml}$ respectively [30]. The ethyl acetate fraction of the fruits of $P$. pashia from China was found to have strong antioxidant activity $\left(\mathrm{IC}_{50}=2.47 \pm\right.$ $0.08 \mu \mathrm{g} / \mathrm{ml})$ followed by butyl alcohol fraction $(5.23 \pm 0.21 \mu \mathrm{g} / \mathrm{ml})$, crude extract $(7.78 \pm 0.13 \mu \mathrm{g} / \mathrm{ml})$, petroleum ether fraction $(68.88 \pm 4.80 \mu \mathrm{g} / \mathrm{ml})$ and aqueous fraction $(167.48 \pm 5.6 \mu \mathrm{g} / \mathrm{ml})$ by DPPH method. The chemical investigation of the extract led to the isolation of 28 important phenolic compounds from the plant. The compound hydroquinone, which is present in the highest proportion may play an important role in the strong antioxidant activity [31].

The antioxidant activity of the leaf extracts in different solvents of $Z$. mauritiana was assessed by different methods. The ethanol extract exhibited the maximum activity with $\mathrm{IC}_{50}$ of $19.44 \pm 0.79 \mu \mathrm{g} / \mathrm{ml}$ as compared to standard ascorbic acid with $\mathrm{IC}_{50}$ of $6.44 \pm 0.20 \mu \mathrm{g} / \mathrm{ml}$ by DPPH assay. The result demonstrated that the radical scavenging activity was due to the flavonoid and phenolic content in the plant [12].

Table 4. $\mathrm{IC}_{50}(\mu \mathrm{g} / \mathrm{ml})$ of the plant extracts and ascorbic acid (Mean $\pm \mathrm{SD}, \mathrm{n}=3$ ).

\begin{tabular}{cc}
\hline Plant extracts & $\mathrm{IC}_{50}(\mu \mathrm{g} / \mathrm{ml})$ \\
\hline Rubus ellipticus & $42.40 \pm 1.5$ \\
Ziziphus mauritiana & $55.67 \pm 7.41$ \\
Pyrus pashia & $58.33 \pm 2.9$ \\
Drynaria coronans & $93.30 \pm 5.19$ \\
Ascorbic acid (Standard) & $28.44 \pm 0.97$
\end{tabular}




\subsection{Antibacterial Activity}

Evaluation of the antibacterial susceptibility of the plant extracts was initially determined by the agar-well diffusion method. The results of the antibacterial susceptibility test are shown in Table 5. The diameter of the zone of inhibition (ZOI) reflects the relative antibacterial activity of the extract. The extracts exhibited no effect on all of the Gram-negative and a significant effect against Gram-positive bacteria, $S$. aureus. The extracts of $R$. ellipticus and $P$. pashia were found to exhibit the highest activities with the zone of inhibition (ZOI) of 17 $\mathrm{mm}$ and $12 \mathrm{~mm}$ respectively. The extracts of $Z$. mauritiana and $D$. coronans showed lower activities with ZOI of $9 \mathrm{~mm}$ and $8 \mathrm{~mm}$ respectively. The effectiveness of the extracts in the tested microorganisms was determined by measuring the minimum inhibitory concentration (MIC) and minimum bactericidal concentration (MBC). The test was performed for the extracts of $R$. ellipticus and $P$. pashia which showed high antibacterial activity. The MIC and MBC of $R$. ellipticus and $P$. pashia were $3.125 \mathrm{mg} / \mathrm{ml}, 12.5 \mathrm{mg} / \mathrm{ml}$, and $12.5 \mathrm{mg} / \mathrm{ml}, 25 \mathrm{mg} / \mathrm{ml}$ respectively are shown in Table 6 and Figure 3.

Table 5. Diameter of ZOI in Agar-well diffusion method.

\begin{tabular}{cccc}
\hline & Bacteria & \multicolumn{2}{c}{ Zone of Inhibition (ZOI) } \\
\cline { 3 - 4 } Plant samples & S. aureus & $17 \mathrm{~mm}$ & Control (Neomycin) \\
\hline R. ellipticus & S. aureus & $9 \mathrm{~mm}$ & $18.5 \mathrm{~mm}$ \\
Z. mauritiana & S. aureus & $12 \mathrm{~mm}$ & $12 \mathrm{~mm}$ \\
P. pashia & S.aureus & $8 \mathrm{~mm}$ & $16.5 \mathrm{~mm}$ \\
D. coronans & & & $15.5 \mathrm{~mm}$ \\
\hline
\end{tabular}

Table 6. MIC and MBC values of plant extracts against $S$. aureus $(\mathrm{mg} / \mathrm{ml})$.

\begin{tabular}{ccc}
\hline Plant samples & MIC & MBC \\
\hline Rubus ellipticus & $3.125 \mathrm{mg} / \mathrm{ml}$ & $12.5 \mathrm{mg} / \mathrm{ml}$ \\
Pyrus pashia & $12.5 \mathrm{mg} / \mathrm{ml}$ & $25 \mathrm{mg} / \mathrm{ml}$ \\
\hline
\end{tabular}

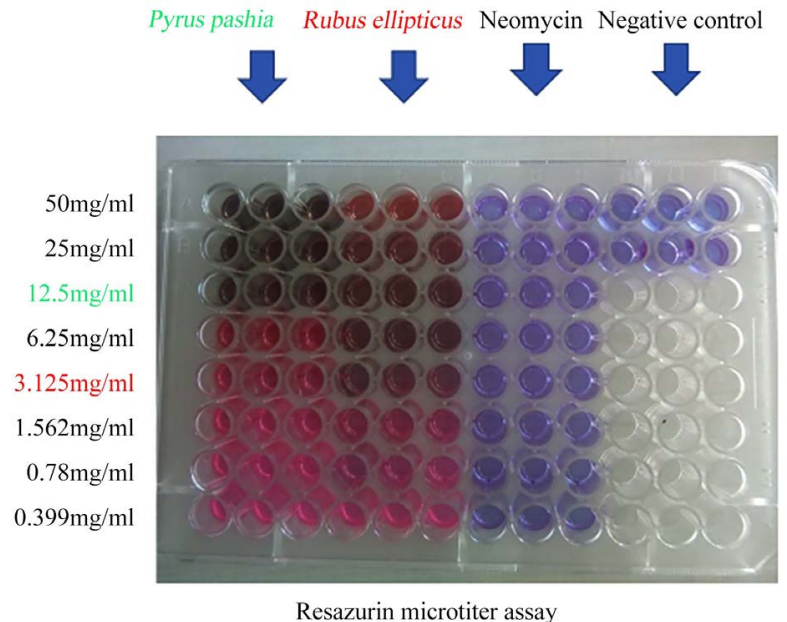

Figure 3. Results of MIC of plant extracts against $S$. aureus $(\mathrm{mg} / \mathrm{ml})$. 
The results of the present study were found comparable to the previously reported results. The antibacterial activity leaf extracts of $R$. ellipticus of Tamil Nadu, India exhibited significant activity against $S$. aureus (MTCC 96). The methanol extracts were evaluated by the disc diffusion method using streptomycin as a control and $16 \mathrm{~mm}, 20 \mathrm{~mm}$, and $22 \mathrm{~mm}$ ZOI was observed for the concentrations of $1.25,2.5$, and $5 \mathrm{mg} / \mathrm{ml}$ respectively. The MIC was determined by the broth microdilution method as $31.25 \mu \mathrm{g} / \mathrm{ml}$ and $250 \mu \mathrm{g} / \mathrm{ml}$ for methanol and ethyl acetate extracts respectively [32]. The ethanolic fruit extract of $R$. ellipticus from Uttarakhand, India was evaluated for the antibacterial activity by a disc diffusion method. The extract exhibited significant activity with ZOI of $16 \pm 1$, $15 \pm 1$ and $15 \pm 1 \mathrm{~mm}$ for E. coli (MTCC 729), Streptococcus pyogenes (MTCC 1925) and E. coli (MTCC 443) at the concentration of $50 \mathrm{mg} / \mathrm{ml}$ respectively [33]. Five cyclopeptide alkaloids were isolated from the methanol root extracts of $Z$. mauritiana from Thailand. The isolated compounds exhibited potent in vitro antiplasmodial activity against Plasmodium falciparum (K1, multidrug-resistant strain) with $\mathrm{IC}_{50}$ values ranging from 3.7 to $10.3 \mu \mathrm{M}$. The alkaloids mauritine $\mathrm{M}$ and nummularine $\mathrm{H}$ exhibited significant antimycobacterial activity against Mycobacterium tuberculosis with the MIC values of 72.8 and $4.5 \mu \mathrm{M}$ respectively [34]. Zizimauritic acid (A-C), ceanothenic acid, betulinic acid, and ceanothic acid were isolated from the roots of $Z$. mauritiana. All the compounds were found inactive against Candida albicans. Zizimauritic acid-A showed the maximum antibacterial effect against Staphylococcus aureus with $\mathrm{IC}_{50}$ of $2.17 \mu \mathrm{g} / \mathrm{ml}$ [35]. A broad spectrum of antibacterial activity was observed on different bacterial strains of leaf extracts of $Z$. mauritiana. The test was performed against both gram-negative and gram-positive bacteria by a disc diffusion method. The ethyl acetate extract was found to have a strong activity with ZOI, MIC, and $\mathrm{MBC}$ of $22.33 \pm 0.58 \mathrm{~mm}, 2.5 \mathrm{mg} / \mathrm{ml}$, and $4 \mathrm{mg} / \mathrm{ml}$ respectively for Vibrio parahaemolyticus (ATCC 17802). Ethyl alcohol extract was effective against Salmonella typhi (ATCC 13311) with ZOI, MIC, and MBC of $19.0 \pm 0.10 \mathrm{~mm}, 4.5$ $\mathrm{mg} / \mathrm{ml}$, and $8 \mathrm{mg} / \mathrm{ml}$ respectively. Kanamycin was taken as a standard that had the ZOI ranging from $26.67 \pm 1.15 \mathrm{~mm}$ to $34.00 \pm 0.00 \mathrm{~mm}$ [12]. The ethanolic extract of the bark of $P$. pashia was found to exhibit a significant antibacterial activity. The disc diffusion method showed the ZOI of $17.0 \pm 1 \mathrm{~mm}, 15.0 \pm 1$ $\mathrm{mm}$, and $14 \pm 1 \mathrm{~mm}$ against $K$. pneumonia, Shigella flexneri, and $E$. coli respectively [36]. The low activity of $D$. coronans is supported by a low antibacterial property of the plant from central Nepal against some of the Gram-positive and Gram-negative bacteria [15].

The plant extracts investigated were found to contain important phytochemicals such as alkaloids, polyphenols, flavonoids, cardiac glycosides, tannins, etc. The presence of alkaloids, phenols, and flavonoids are responsible for different kinds of biological properties [32]. Flavonoids are very important secondary metabolites reported to possess antibacterial, antiviral anti-inflammatory, enzyme inhibition, cytotoxic, antitumor, antioxidant properties [37]. Glycosides support the defense mechanism against microbes, insects, and herbivores. Sapo- 
nins exhibit significant hypo cholesterol, hypertensive, and cardiac depressant properties [38].

The evaluation of the extract in different fractions would give better insights into their biological properties. The antioxidant activities could be evaluated by using different methods. Multidrug resistance bacterial strains could also be used. The plants were collected in only one season from August to July. That's why the fluctuations in the results of the biological activities due to seasonal variation could not be addressed

\section{Conclusion}

This study suggests the crude methanol extracts of $R$. ellipticus and $P$. pashia are found to exhibit potent antioxidant and antibacterial activity that provides the partial scientific validation for using these plants against infectious diseases in different communities of Kaski district Nepal. The results indicated that plants are the good sources of secondary metabolites from which pure compound can be isolated and perform in-vivo biological activities with the mechanism of action to develop products for the herbal remedy against infectious diseases.

\section{Acknowledgements}

Authors are grateful to the Central Department of Chemistry, Tribhuvan University, for providing laboratory facility and Prithvi Narayan Multiple Campus, Pokhara for granting the study leave to Lekha Nath Khanal. We are thankful to National Herbarium and Plant Resources, Ministry of Forest and Soil Conservation, Godawari, Nepal for the identification of the plants.

\section{Conflicts of Interest}

The authors declare no conflicts of interest regarding the publication of this paper.

\section{References}

[1] Mohankumar, J.B., Gladious, A.J. and Velvizhi, M. (2017) Antioxidant Content of Selected Medicinal Plants Used by Kaani Tribes of Kanyakumari District in Tamilnadu India. Journal of Food and Nutrition Research, 5, 180-186.

[2] IUCN-Nepal (2000) National Register of Medicinal Plants. IUCN Nepal, Kathmandu.

[3] Gaire, B.P. and Subedi, L. (2011) Medicinal Plant Diversity and Their Pharmacological Aspects of Nepal Himalayas. Pharmacognosy Journal, 3, 6-17. https://doi.org/10.5530/pj.2011.25.2

[4] Pokharel, K., et al. (2008) Antibacterial Activities of Medicinal Plants of Nepal. Journal of the Institute of Medicine, 30, 28-32.

[5] Harathi, K., Giribabu, D. and Naidu, C.V. (2017) Phytochemical Evaluation and in Vitro Antibacterial Activity of Sphaeranthus indicus (L.) - An Important Antijaundice Medicinal Plant. American Journal of Plant Sciences, 8, 1011-1021. https://doi.org/10.4236/ajps.2017.85067 
[6] Liu, R.H. (2013) Health-Promoting Components of Fruits and Vegetables in the Diet. Advances in Nutrition, 4, 384S-392S. https://doi.org/10.3945/an.112.003517

[7] Ahmed, S.R., et al. (2019) Phytochemical Screening, Antioxidant and Antibacterial Activity of Some Medicinal Plants Grown in Sylhet Region. Journal of Pharmaceutical and Biological Sciences, 14, 26-37.

[8] Pandey, Y. and Bhatt, S.S. (2016) Overview of Himalayan Yellow Raspberry (Rubus ellipticus Smith.): A Nutraceutical Plant. Journal of Applied and Natural Science, 8 , 494-499. https://doi.org/10.31018/jans.v8i1.824

[9] Uprety, Y., Poudel, R.C., Asselin, H. and Boon, E. (2011) Plant Biodiversity and Ethnobotany inside the Projected Impact Area of the Upper Seti Hydropower Project, Western Nepal. Environment, Development and Sustainability, 13, 463-492. https://doi.org/10.1007/s10668-010-9271-7

[10] Siddiqui, S.Z., et al. (2015) Pyrus pashia: A Persuasive Source of Natural Antioxidants. Pakistan Journal of Pharmaceutical Sciences, 28, 1763-1772.

[11] Lia, Z., et al. (2015) Terpenoids with Cytotoxic Activity from the Branches and Leaves of Pyrus pashia. Phytochemistry Letters, 13, 246-251.

https://doi.org/10.1016/j.phytol.2015.06.015

[12] Jain, P., Haque, A., Islam, T., Alam, A. and Reza, H.M. (2019) Comparative Evaluation of Ziziphus mauritiana Leaf Extracts for Phenolic Content, Antioxidant and Antibacterial Activities. Journal of Herbs, Spices \& Medicinal Plants, 25, 236-258. https://doi.org/10.1080/10496475.2019.1600627

[13] Jain, A., Bhatt, S. and Dhyani, S. (2012) Phytochemical Screening of Secondary Metabolites of Ziziphus mauritiana Lam. Bark. International Journal of Current Pharmaceutical Research, 4, 156-159.

[14] Malla, B., Gauchan, D.P. and Chhetri, R.B. (2015) An Ethnobotanical Study of Medicinal Plants Used by Ethnic People in Parbat District of Western Nepal. Journal of Ethnopharmacology, 165, 103-117. https://doi.org/10.1016/j.jep.2014.12.057

[15] Subba, B. and Basnet, P. (2014) Antibacterial Activity of Some Medicinal Plants from East and Central Part of Nepal. International Journal of Applied Sciences and Biotechnology, 2, 88-92. https://doi.org/10.3126/ijasbt.v2i1.9697

[16] Chang, H.-C., Huang, G.-J., Agrawal, D.C., Kuo, C.-L., Wu, C.-R. and Tsay, H. (2007) Antioxidant Activities and Polyphenol Contents of Six Medicinal Ferns Used as "Gusuibu". Botanical Studies, 48, 3977-406.

[17] Antara, S. and Batra, A. (2012) Evaluation of Antimicrobial Activity of Different Solvent Extracts of Medicinal Plant: Melia azedarach L. International Journal of Current Pharmaceutical Research, 4, 67-73.

[18] Minakshi, B. Jharna, D. Chanbi, D.E., Nayan, T., Kundal, N., Sarma, M and Kalita, P.P. (2016) Phytochemical Analysis of Traditional Medicinal Plants and Their Antimicrobial Activity: An Experience from North East India. Journal of Pharmacy Research, 1, Article ID: 000104. https://doi.org/10.23880/OAJPR-16000104

[19] Murray, R.P., Baron, E.J., Jorgensen, J.H., Landry, M.L. and Pfaller, M.A. (2007) Manual of Clinical Microbiology. 9th Edition, The American Society for Microbiology, Washington.

[20] Nasir, B., Fatima, H., Ahmad, M. and Haq, I.U. (2015) Recent Trends and Methods in Antimicrobial Drug Discovery from Plant Sources. Austin Journal of Microbiology, 1, 1-12.

[21] Sarker, S.D., Nahar, L. and Kumarasamy, Y. (2007) Microtitre Plate-Based Antibacterial Assay Incorporating Resazurin as an Indicator of Cell Growth, and Its Appli- 
cation in the in Vitro Antibacterial Screening of Phytochemicals. Methods, 42, 321-324. https://doi.org/10.1016/j.ymeth.2007.01.006

[22] Blois, M.S. (1958) Antioxidant Determinations by the Use of a Stable Free Radical. Nature, 181, 1199-1200. https://doi.org/10.1038/1811199a0

[23] Sharopov, F.S., Wink, M. and Setzer, W.N. (2015) Radical Scavenging and Antioxidant Activities of Essential Oil Components-An Experimental and Computational Investigation. Natural product communications, 10, 153-156. https://doi.org/10.1177/1934578X1501000135

[24] Khan, W., et al. (2019) Antioxidant Potential, Phytochemicals Composition, and Metal Contents of Datura alba. BioMed Research International, 2019, Article ID: 2403718. https://doi.org/10.1155/2019/2403718

[25] Bertleff-Zieschang, N. et al. (2017) Biofunctional Metal-Phenolic Films from Dietary Flavonoids. Chemical Communications, 53, 1068-1071. https://doi.org/10.1039/C6CC08607A

[26] Abbasi, M.A., et al. (2010) Evaluation of Comparative Antioxidant Potential of Aqueous and Organic Fractions of Ipomoea carnea. Journal of Medicinal Plants Research, 4, 1883-1887.

[27] Subba, B., Gaire, S. and Sharma, K.R. (2019) Analysis of Phytoconstituents, Antioxidant, and Alpha Amylase Inhibitory Activities of Persea americana MILL, Rhododendron arboretum SM. Rubus ellipticus SM. From Arghakhanchi District Nepal. Asian Journal of Pharmaceutical and Clinical Research, 12, 301-304. https://doi.org/10.22159/ajpcr.2018.v12i1.29679

[28] George, B.P. and Parimelazhagan, T. (2013) Antitumor and Wound Healing Properties of Rubus ellipticus Smith. Journal of Acupuncture and Meridian Studies, 8 , 134-141

[29] Duraiswamy, B., Singanan, M. and Varadarajan, V. (2018) Physicochemical, Phytochemicals and Antioxidant Evaluation of Guazuma ulmifolia Fruit. International Journal of Pharmacy and Pharmaceutical Sciences, 10, 87-91. https://doi.org/10.22159/ijpps.2018v10i9.26778

[30] Tsering, J., Gogoi, B.J. and Tag, H. (2012) Ethnobotany and Phytochemical Analysis of Pyrus pashia Leaves. International Journal of Pharmaceutical Sciences and Research, 3, 2721-2725.

[31] He. J., et al. (2015) Phenolic Compounds and Antioxidant Activities of Edible Flowers of Pyrus pashia. Journal of Functional Foods, 17, 371-379.

https://doi.org/10.1016/j.jff.2015.05.045

[32] Latha, R., Sarkar, T. and Jansy, S. (2015) Evaluation of Antimicrobial Efficiency and Alpha-Glucosidase Inhibition of Rubus ellipticus Smith. Leaf Extracts and Its Phytochemical Analysis. Asian Journal of Pharmaceutical and Clinical Research, 8, 422-426.

[33] Saklani, S., Chandra, S., Badoni, P. and Dogra, S. (2012) Antimicrobial Activity, Nutritional Profile and Phytochemical Screening of Wild Edible Fruit of Rubus ellipticus. International Journal of Medicinal and Aromatic Plants, 2, 269-274.

[34] Panseeta, P., et al. (2011) Antiplasmodial and Antimycobacterial Cyclopeptide Alkaloids from the Root of Ziziphus mauritiana. Phytochemistry, 72, 909-915. https://doi.org/10.1016/j.phytochem.2011.03.003

[35] Ji, C.J., Zeng, G.Z., Han, J., He, W.J., Zhang, Y.M. and Tan, N.H. (2012) Zizimauritic Acids A-C, Three Novel Nortriterpenes from Ziziphus mauritiana. Bioorganic \& Medicinal Chemistry Letters, 22, 6377-6380. 
[36] Saklani, S. and Kothiyal, S.C. (2012) In Vitro Antimicrobial Activity Nutritional Profile of Medicinal Plant of Garhwal, Himalaya. International Journal of Pharmaceutical Sciences and Research, 3, 268-272.

[37] Cushnie, T.P.T. and Lamb, A.J. (2005) Antimicrobial Activity of Flavonoids. International Journal of Antimicrobial Agents, 26, 343-356.

https://doi.org/10.1016/j.ijantimicag.2005.09.002

[38] Sharma, K.R., Kumar, S., Karna, L., Kalauni, S.K. and Pokharel, Y.R. (2017) Phytochemical Analysis and In-Vitro Antimicrobial Screening of Some Selected Medicinal Plants of Nepal. International Journal of Recent Scientific Research, 8, 14986-14994. 